\title{
The impact of land-use change on water-related ecosystem services: a study of the Guishui River Basin, Beijing, China
}

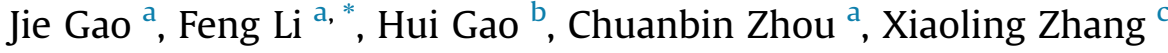 \\ a State Key Laboratory of Urban and Regional Ecology, Research Center for Eco-Environmental Sciences, Chinese Academy of Sciences, Beijing 100085, China \\ ${ }^{\mathrm{b}}$ College of Urban and Environmental Science, Xinyang Normal University, Xinyang 46400, Henan, China

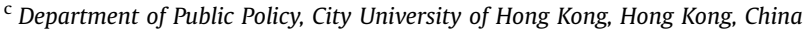

\section{A R T I C L E I N F O}

\section{Article history:}

Received 1 September 2015

Received in revised form

20 January 2016

Accepted 20 January 2016

Available online 29 January 2016

\section{Keywords:}

Land-use change

Ecosystem services

Scenario analysis

Integrated Valuation of Ecosystem Services and Tradeoffs (InVEST)

Guishui River Basin

\begin{abstract}
A B S T R A C T
Land-use change is a significant driver of ecosystem service changes. This paper explores how land-use change affects water-related ecosystem services (e.g., water yield, water purification, and soil conservation) in the Guishui River Basin, Beijing, China. Water-related ecosystem services in the Basin are vitally important for Beijing, which currently faces a severe water crisis. Understanding the impacts of land-use change on water-related ecosystem services is essential for effectively managing this crisis. To this end, the study first analyzed land-use change and corresponding variations in water-related ecosystem services in the Basin from 1980 to 2011. The analysis showed that increases in woodland and construction land enhanced water yield and soil conservation services while reforestation and urbanization degraded water purification services. The paper then developed four spatially-explicit landuse scenarios, corresponding to water conservation, agricultural expansion, a combination, and soil conservation. Each scenario quantified the impact of future land-use changes on water-related ecosystem services. This research found that water purification and soil conservation services increased under both the water conservation and soil conservation scenarios, while these services decreased under the agricultural expansion scenario. Water yield also increased under the soil conservation scenario. Overall, the paper shows that ecosystem services are spatially specific and greatly affected by different scenarios. This finding underscores the value of studies to improve land management practices. In particular, this research would be useful for those policymakers and stakeholders that intend to forecast the impacts of alternative land-use policies on water-related ecosystem services. The limitations and shortcomings of this study, including accuracy in estimating ecosystem services, are discussed.
\end{abstract}

() 2016 Elsevier Ltd. All rights reserved.

\section{Introduction}

Ecosystem service assessments have gained increasing attention in recent years (Cao et al., 2015; Fisher et al., 2009; Seppelt et al., 2011). Ecosystem services represent the benefits that living organisms derive from ecosystem functions that maintain the Earth's life support systems (MA, 2005). According to the Millennium Ecosystem Assessment (MA), two thirds of all ecosystem services have declined over the last 50 years, and this decline is likely to have large, negative impacts on human welfare (MA, 2005). Landuse change, which influences ecosystem properties, processes, and components, has been identified as a significant driver of change in ecosystem services (de Groot et al., 2010). For instance,

\footnotetext{
* Corresponding author. Tel./fax: +86 1062849103.

E-mail address: lifeng@rcees.ac.cn (F. Li).
}

many studies have shown that land-use change can decrease ecosystem services, such as pollination services (Priess et al., 2007; Ricketts et al., 2008), carbon storage (Tao et al., 2015), water yield (Jia et al., 2014; Zhuang et al., 2010), and soil conservation (Bai et al., 2012).

Scenario analysis is commonly used to evaluate the future impact of land-use changes on ecosystem services to inform policymaking and stakeholder decisions about optimal ecosystemservice provision (Bennett et al., 2009; Geneletti, 2013). Polasky et al. (2010) evaluated the impacts of a suite of different land-use change scenarios on water quality in Minnesota, USA, finding that agricultural expansion led to large declines in water quality and carbon storage. Shoyama and Yamagata (2014) analyzed scenarios of land-cover change in a Japanese watershed to show that, absent conservation measures, supporting and provisioning ecosystem services will decline if the timber and agricultural industries remain small until 2060. Nelson et al. (2010) proposed two 
plausible scenarios of 2000-2015 global area change in urban land and cropland, suggesting that urban area and croplands will expand to meet human needs for living space and food. Estoque and Murayama (2012) examined the potential impacts of future land-use changes on ecosystem services, finding that the total value of ecosystem services will decrease by 2020 if current urbanization patterns continue. Logsdon and Chaubey (2013) created three landuse scenarios for watershed provision of services, finding that erosion regulation improved under both the forested and urban scenarios. Chuai et al. (2015) designed two development scenarios to predict land-use structure in 2020, indicating that the limitation of built-up land plays a key role in reducing carbon emissions.

Several models have been employed to investigate the relationship between land-use change and water-related ecosystem services under different scenarios, including Integrated Valuation of Ecosystem Services and Tradeoffs (InVEST) (Tallis and Polasky, 2009; Vigerstol and Aukema, 2011), Artificial Intelligence for Ecosystem Services (ARIES) (Villa et al., 2014), and Soil and Water Assessment Tool (SWAT) (Logsdon and Chaubey, 2013). Compared with SWAT and ARIES, InVEST is more appropriate for assessing the impacts of land-use change on multiple ecosystem services (Vigerstol and Aukema, 2011). Indeed, it has been applied all over the world for such assessments. For instance, Hamel et al. (2015) used InVEST to assess soil conservation in the Cape Fear basin, North Carolina. Goldstein et al. (2012) used InVEST with Kamehameha Schools, a large landowner in Hawaii, to assess how to maximize ecosystem service provision and revenue. Shoyama and Yamagata (2014) used InVEST to map the provision of selected ecosystem services (e.g., water yield, carbon storage, habitat quality) in the rural Kushiro watershed, northern Japan. Tao et al. (2015) used InVEST to assess the spatial distribution and dynamic variation of terrestrial carbon stocks in Changzhou, China. Finally, Polasky et al. (2010) used InVEST to assess the provision and value of ecosystem services and species habitat under different land-use scenarios in Minnesota. In sum, InVEST has been shown to reliably assess multiple ecosystem services, including water-related ecosystem services, providing useful information to policymakers and stakeholders weighing the tradeoffs between ecosystem service provision and other objectives (Logsdon and Chaubey, 2013; Polasky et al., 2010).

Here, this study used InVEST to assess how land-use change affects water-related ecosystem services under different land-use scenarios in the Guishui River Basin. The Basin is a critical part of Beijing's metropolitan area because its downstream portion includes a water conservation project, the Guanting Reservoir, which in 1997 lost its ability to supply drinking water to Beijing (He et al., 2011). Such water-related crises, including water shortages, water pollution, and soil erosion, are among the most serious problems that Beijing faces (Xu et al., 2015). To address these problems, the local government initiated a series of land policies, including the Paddy Land-to-Dry Land program as well as a reforestation program (Zheng et al., 2013). The areas where land policies were implemented have experienced dramatic changes in land use with potentially important implications for ecosystem services and human welfare.

The paper assessed land-use change and changes in waterrelated ecosystem services in the Guishui River Basin over the period 1980-2011. During this period, the Guishui River Basin experienced its rapid economic growth and increasing urbanization (from 11\% to 42\%) (He et al., 2016). The land-use policies aimed at mitigating the negative consequences of economic growth and urbanization on the environment were also implemented during this period. After assessing the impacts of urban expansion and land-use policies on ecosystem service provision over this period, the study analyzed future changes in service provision to enable policymakers and other stakeholders to optimize land use in the Basin.

\section{Materials and methods}

The affects of land-use change on water-related ecosystem services were assessed for the Guishui River Basin, Beijing, China. Water-related ecosystem services in Guishui River Basin are vitally important for Beijing, which currently faces a severe water crisis.

\subsection{Study area}

The Guishui River Basin is located in northwest Beijing, China (Fig. 1). It ranges from $40^{\circ} 19^{\prime}$ to $40^{\circ} 38^{\prime} \mathrm{N}$ in latitude and from $115^{\circ} 48^{\prime}$ to $116^{\circ} 20^{\prime} \mathrm{E}$ in longitude. The Basin covers a total area of $1003 \mathrm{~km}^{2}$; its elevation ranges from 470 to $2173 \mathrm{~m}$. The Basin's annual average temperature is $8{ }^{\circ} \mathrm{C}$, and its annual average precipitation is approximately $390 \mathrm{~mm}$, with $70-80 \%$ of the rainfall occurring in the rainy season from July to September. As mentioned earlier, the Basin is in Beijing's metropolitan area, which has experienced rapid urbanization in the past 30 years. Because of this urbanization, the Basin has experienced significant changes in land use and land-use policies. Since land use influences ecosystem structure, hydrological processes and functions (Zhuang et al., 2010), changes in land use are likely to cause changes in waterrelated ecosystem services, including water provision, water purification, and soil conservation (de Groot et al., 2010).

\subsection{Land-use change and scenario analysis}

Land-use maps from 1980 to 2011 were created to identify the factors driving past land-use change. Based on this analysis, four land-use scenarios were developed to assess future change.

\subsubsection{Detecting past land-use change}

To detect the trends in past land-use change, maps of land use in 1980, 1995, and 2011 were prepared. Typical land uses in the study area were classified as woodland, including evergreen coniferous woodland, deciduous broad-leaf woodland and mixed broadleafconifer woodland; cropland, including dry cropland of various slopes and, irrigated cropland; grassland, including typical grassland and shrub land; water bodies, including swamp, lake, river, and wetland; and construction land, including urban construction land, rural settlement, and transport facility areas. A transition matrix was constructed to show the amount of changes in each land use between 1980, 1995, and 2011.

\subsubsection{Future scenario analysis}

Based on analysis of the factors driving past land-use change and the consequences of land-use policies implemented by the local government from 1980 to 2011, the study developed four land-use scenarios to explore the potential impact of land-use changes on ecosystem services: a water conservation scenario, an agricultural expansion scenario, a combined scenario, and a soil conservation scenario. Land use in 2011 was served as the baseline (denoted as the Base Landscape). In the water conservation scenario, which aimed to improve water quality in the Basin, all lands within 100-m of streams in the Guishui River Basin were converted to vegetative buffer strips. These lands along the river were croplands and were transformed to woodlands. In the agricultural expansion scenario, which aimed to increase food-provisioning services, the woodlands and grasslands that have a slope gradient of less than $6^{\circ}$ were converted to croplands because these flatlands were suitable for agricultural development. In the 


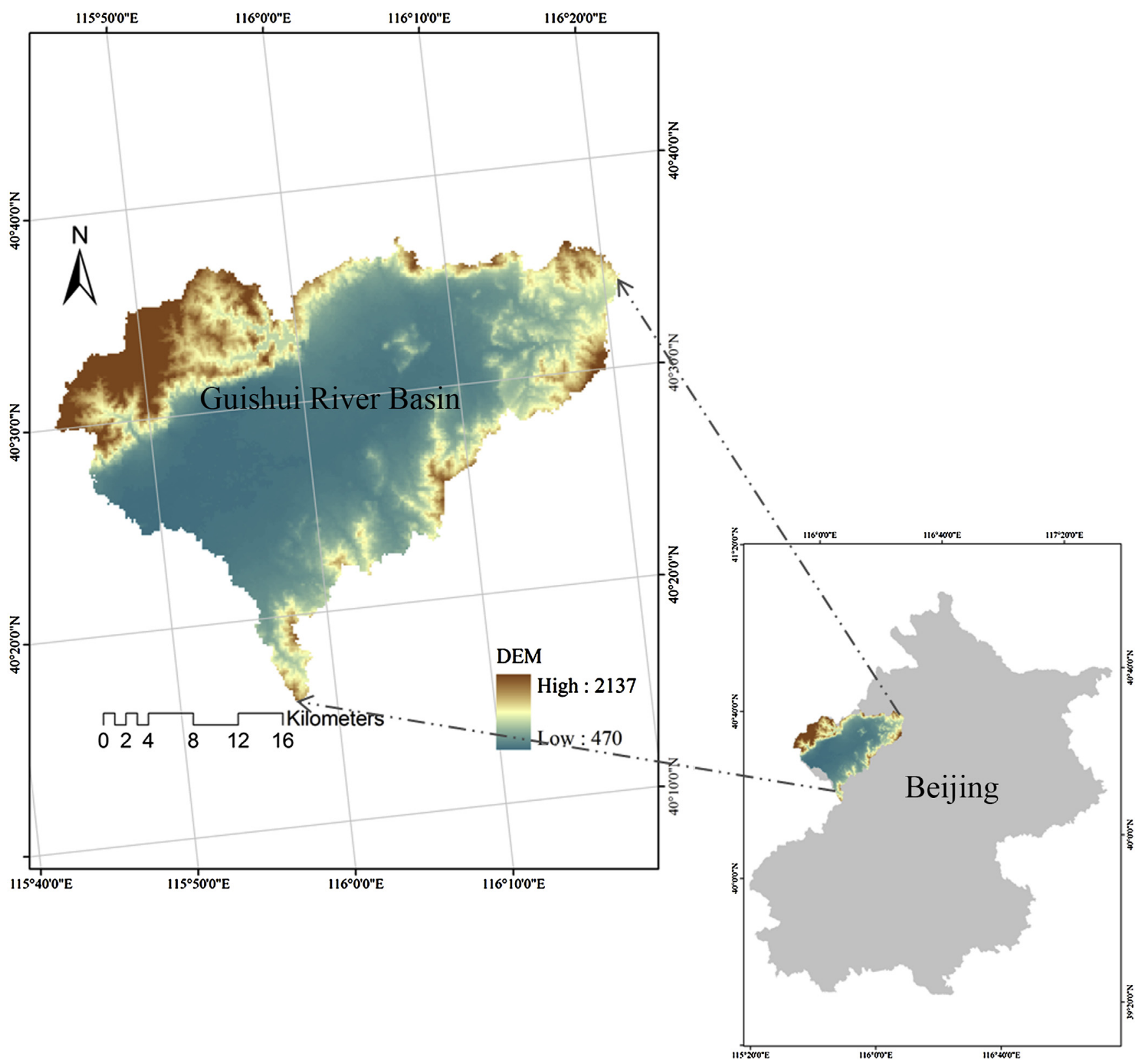

Fig. 1. Location of the Guishui River Basin.

combined scenario (agricultural expansion with buffer strips), $100 \mathrm{~m}$ buffer strips were added on fields adjacent to streams in the agricultural expansion scenario to reduce nutrient and sediment runoff. Finally, in the soil conservation scenario, which aimed to reduce soil loss, croplands with a slope angle between $6^{\circ}$ and $15^{\circ}$ were transformed to grasslands because these sloping highlands easily cause soil loss.

\subsection{Methods to quantify ecosystem services}

InVEST is a set of spatial models that analyze and predict the provision of ecosystem services and habitat provision, given landuse maps and related biophysical, economic, and institutional data for a given region (Tallis et al., 2013). The paper analyzed and predicted ecosystem services in the Guishui River Basin using InVEST's water yield, soil conservation, and water purification models. All spatial analyses were performed using ArcGIS ver.9.3.

\subsubsection{Water yield}

Water yield is defined as the amount of water runoff from the landscape, and its relative volume affects the quality of life for local residents. The water yield model is based on the Budyko curve and annual average precipitation. The paper determined the water yield $Y(x)$ for each pixel on the landscape $x$ using Eq. (1).

$Y_{X}=\left(1-\frac{A E T_{X}}{P_{X}}\right) \cdot P_{X}$

where, $Y_{X}$ is the water yield for pixel $x, A E T_{X}$ is the annual actual evapotranspiration for pixel $\mathrm{x}$, and $P_{X}$ is the annual precipitation on pixel $x$.

\subsubsection{Soil conservation}

Soil conservation, a relative measurement of soil loss, is regarded as one of the most crucial ecosystem services in the Guishui 
River Basin. Reductions in soil loss imply improvements in soil conservation. The universal soil loss equation (USLE) was used to evaluate soil conservation. The research predicted the rate of soil loss for each pixel on the landscape $x$ using Eq. (2).

$U S R L_{x}=R_{x} \cdot K_{x} \cdot L S_{x} \cdot C_{x} \cdot P_{x} \lim _{x \rightarrow \infty}$

where, $U S R L_{x}$ is the average annual soil loss for pixel $x ; R_{x}$ is the rainfall factor for pixel $x ; K_{x}$ is the soil erodibility factor for pixel $x$; $L S_{x}$ is the field topography factor for pixel $x ; C_{x}$ is the cropping and management factor for pixel $x$, and $P_{x}$ is the factor for supporting conservation practices for pixel $x$.

\subsubsection{Water purification}

Water purification, an essential service provided by ecosystems, is focused on the relative export of total dissolved nitrogen as a proxy for pollution. The water purification service refers to the capacity of ecosystems to mitigate water pollution by retaining some non-point source pollutants through the action of vegetation and soil. A major impact of land use on water quality is the contribution of nutrients to surface water. The nitrogen export for each pixel on the landscape $x$ can be calculated using Eqs. (3)-(5).

$A L V_{x}=H S S_{x} \cdot$ pol $_{x}$

where, $A L V_{x}$ is the Adjusted Loading Value at pixel $x$, pol $_{x}$ is the export coefficient at pixel $x$, and $H S S_{x}$ is the Hydrologic Sensitivity Score at pixel $x$ which is calculated as:

$H S S_{x}=\frac{\lambda_{x}}{\bar{\lambda}_{w}}$

where, $\lambda_{x}$ is the runoff index at pixel $x$, calculated using the following equation, and $\bar{\lambda}_{w}$ is the mean runoff index in the watershed of interest.

$\lambda_{x}=\log \left(\sum_{U} Y_{U}\right)$

where, $\sum Y_{U}$ is the sum of the water yield of pixels along the flow path abobe pixel $x$ (it also includes the water yield of pixel $x$ ).

\section{Results}

Past land-use changes and their impacts on water-related ecosystem services were assessed. Then, the effects of four landuse scenarios on water-related ecosystem services were evaluated. Finally, the provision of ecosystem services under the baseline and four scenarios was quantified.

\subsection{Land-use change from 1980 to 2011}

Maps of land use in 1980, 1995, and 2011 are shown in Fig. 2. Different land-use types changed drastically from 1980 to 1995 and from 1995 to 2011. Most notably, these periods were characterized by woodland expansion and cropland shrinkage (Table 1). Indeed, cropland and woodland were the two largest land-use types in the study area, covering more than $80 \%$ of the total area. Grassland, water bodies, and constructed land accounted for only a small portion of the study area. Specifically, cropland covered 43,264 ha in 1980 but only 27,726 ha in 2011, a reduction of approximately $36 \%$. Conversely, woodland increased by $51 \%$ from 1980 to 2011.

Between 1980 and 1995, 6332 ha (15\%) and 3204 ha (7\%) of cropland were converted to woodland and grassland, respectively.
During this same period, grassland experienced a total reduction of about $66 \%$, as a result of conversion to cropland (13\%) and woodland (53\%). Between 1995 and 2011, a further 7599 ha (23\%) and 5400 ha $(16 \%)$ of cropland were converted to woodland and constructed land, respectively. During this same period, 2562 ha (53\%), 821 ha (17\%), and 620 ha (13\%) of water body were converted to cropland, woodland, and constructed land, respectively. Between 1980 and 2011, a total of 20,864 ha of cropland were converted into off-farm land-use types (48\% of the original cropland area), of which 10,901 ha (25\% of the original cropland) and 7495 ha (17\% of the original cropland) of cropland were converted to woodland and constructed land, respectively. Constructed land increased by $209 \%$, mainly as a result of encroachment into cropland and grassland. In summary, the Guishui River Basin underwent a conversion of land use from cropland and grassland to woodland and construction land.

\subsection{Comparison of ecosystem services based on past land-use change}

Ecosystem services in the Basin were altered by the land-use changes described in the previous section (Table 2). Specifically, water yield decreased (-6.65\%) from 1980 to 1995 as a result of woodland expansion and cropland shrinkage. Between 1995 and 2011, the Basin experienced accelerated urbanization. Hence, water yield in this period experienced a moderate increase $(+8 \%)$ resulting from reduced infiltration and faster runoff, where urban growth lead to an increase in impervious surface. This is because when the cropland and woodland were converted to urban land, the amount of impervious surface area increased, which decreased evapotranspiration $\left(\mathrm{ET}_{\mathrm{a}}\right)$ and the infiltration of precipitation, thereby increasing water yield.

Water purification also changed from 1980 to 2011. Water purification was enhanced due to a 5.4\% decline in nitrogen exports compared with the 1980 level. This result suggests that ecological restoration efforts by the Beijing Government (i.e., conversion from croplands to woodlands) resulted in positive impacts on water quality. However, from 1995 to 2011, construction land increased by a factor of 2.65 - from 4158 to 11,000 ha. Accordingly, nitrogen exports increased by $11.6 \%$, from $117.2 \mathrm{t}$ in 1995 to $130.8 \mathrm{t}$ in 2011 , as construction areas generate high nitrogen exports per unit area.

Finally, soil conservation increased from 1980 to 2011 as soil exports decreased by 24.6\%. However, from 1995 to 2011, soil conservation decreased as soil exports increased by $25.9 \%$. Compared with the previous period, grassland suffered a greater loss, by a factor of 3.53. This loss of grassland resulted in increased soil loss in comparison with the earlier period.

\subsection{Comparison of the ecosystem services based on future scenarios}

The sum of water yield, nitrogen exports, and soil exports in the Base Landscape and the four scenarios are shown in Table 3. The water conservation scenario performed well in soil conservation and water purification, showing decreases in water yield, soil and nitrogen exports compared with the 2011 baseline. Water quality in the Basin improved under the water conservation scenario with a large decline of 18.7 tons (14.2\%) in annual nitrogen exports and a moderate decline of 150 tons (3.8\%) in annual soil exports. Most of the water quality improvement came from adding $100-\mathrm{m}$ buffer strips along the Guishui River. However, the water conservation scenario did relatively poorly on water yield due to the expansion of woodland.

With woodland and grassland converted into agriculture, the agricultural expansion scenario resulted in significant changes in 

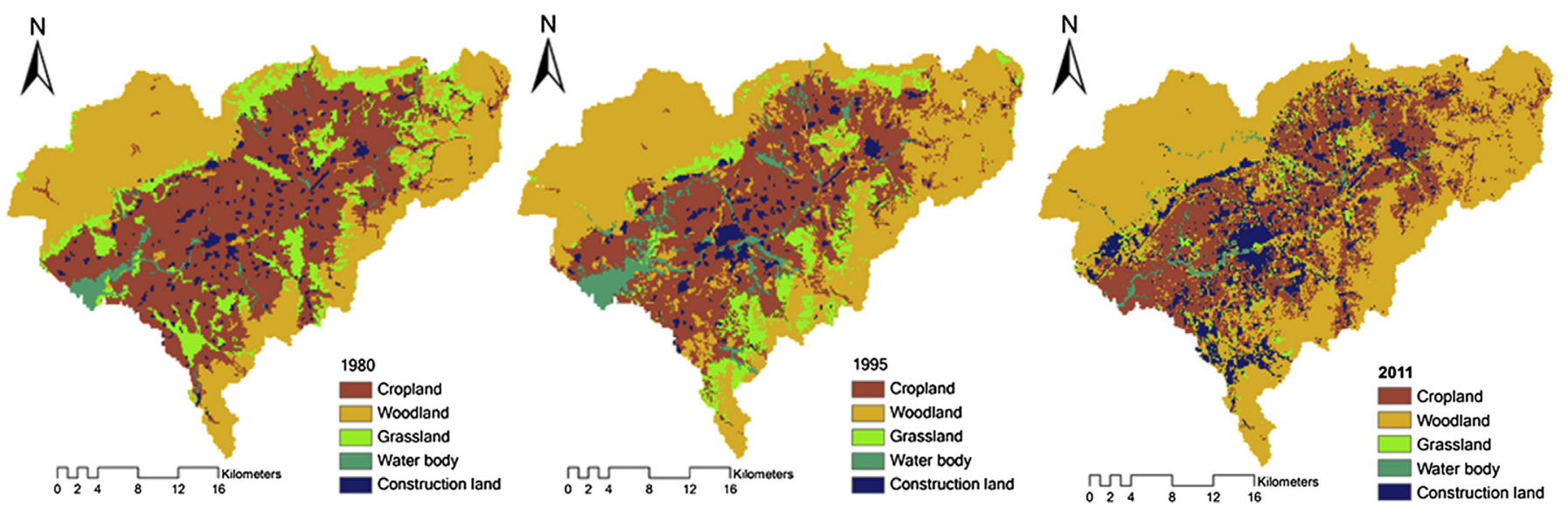

Fig. 2. Land-use maps of the Guishui River Basin in 1980, 1995 and 2011.

Table 1

Areas and proportions of land-use type in 1980, 1995 and 2011.

\begin{tabular}{|c|c|c|c|c|c|c|}
\hline & \multicolumn{2}{|l|}{1980} & \multicolumn{2}{|l|}{1995} & \multicolumn{2}{|l|}{2011} \\
\hline & Area/ha & Percentage/\% & Area/ha & Percentage/\% & Area/ha & Percentage/\% \\
\hline Cropland & 43,264 & 43.1 & 33,501 & 33.4 & 27,726 & 27.6 \\
\hline Woodland & 38,015 & 37.9 & 48,622 & 48.5 & 57,361 & 57.2 \\
\hline Grassland & 13,479 & 13.4 & 9214 & 9.2 & 2607 & 2.6 \\
\hline Water body & 2028 & 2.0 & 4849 & 4.8 & 1649 & 1.6 \\
\hline Construction land & 3556 & 3.5 & 4158 & 4.1 & 11,000 & 11.0 \\
\hline
\end{tabular}

Table 2

Variations of ecosystem services provision from 1980 to 2011.

\begin{tabular}{llll}
\hline & Water yield $\left(10 \mathrm{e} 7 \mathrm{~m}^{3} / \mathrm{a}\right)$ & Soil export (ton/a) & Nitrogen export (ton/a) \\
\hline 1980 & 1.277 & 8872 & 123.936 \\
1995 & 1.192 & 6691 & 117.223 \\
2011 & 1.287 & 8423 & 130.832 \\
\hline
\end{tabular}

conservation was greatly enhanced in this scenario by the expansion of grassland and consequent declines in soil exports. The combined scenario, as compared with the baseline, modestly decreased the water yield by $3.9 \%$. This scenario increased the nitrogen and soil exports by $4.4 \%$ and $5.1 \%$ in the Guishui River Basin,

Table 3

Ecosystem services for the Base Landscape and four scenarios.

\begin{tabular}{|c|c|c|c|}
\hline & Water yield (10e7 m³/a) & Soil export (ton/a) & Nitrogen export (ton/a) \\
\hline Base landscape & 1.287 & 8423 & 130.832 \\
\hline Water conservation & 1.239 & 8264 & 112.271 \\
\hline Agricultural expansion & 1.238 & 9795 & 131.495 \\
\hline Combined scenario & 1.237 & 8853 & 125.027 \\
\hline Soil conservation & 1.340 & 7057 & 111.737 \\
\hline
\end{tabular}

ecosystem services. This scenario, as compared with the Base Landscape, modestly increased the water yield by $3.8 \%$ and slightly increased the nitrogen exports by $0.5 \%$ in the Guishui River Basin. Soil exports greatly increased, rising by $16.3 \%$. Agricultural expansion increased total nitrogen loading, which can lead to an overall deterioration in water quality. Expansion of the agriculture area increased the soil erosion, which can also lead to decreased soil productivity. The reason for this is that natural forest, prairies, and scrublands with relatively low natural erosion rates and higher soil retention were removed after agriculture expansion [similar to Bai et al. (2012)].

After the transition from cropland to grassland, water yield in the soil conservation scenario increased by $4.1 \%$ because the $\mathrm{ET}_{\mathrm{a}}$ of cropland is higher than that of grassland. Nitrogen exports declined by $14.6 \%$, leading to a dramatic improvement in water quality. Soil compared with the 2011 level. However, compared with the agricultural expansion scenario, the combined scenario showed slight declines in nitrogen and soil exports. The results of the combined scenario indicated that adding $100-\mathrm{m}$ buffer strips can mitigate pollution caused by agricultural expansion.

Fig. 3 shows the spatial characteristics of ecosystem services under the Base Landscape and each scenario. High value areas for water yield were mainly distributed in the urban area of the Guishui River Basin because of high runoff coefficients in this region. Low value areas were distributed in the forest region. The greatest nitrogen exports were found in the agricultural and urban areas. Agricultural fields and urban areas are the primary source of nitrogen. The lowest soil exports were found in areas with flat terrain and low-erosive rainfall, with substantially greater exports in the higher-elevation region. 
$N$

(A)

(B)

(C)
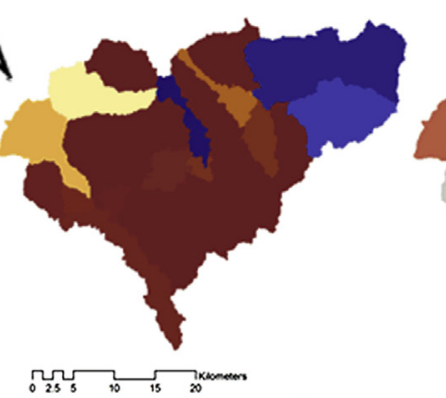

Base Landscape
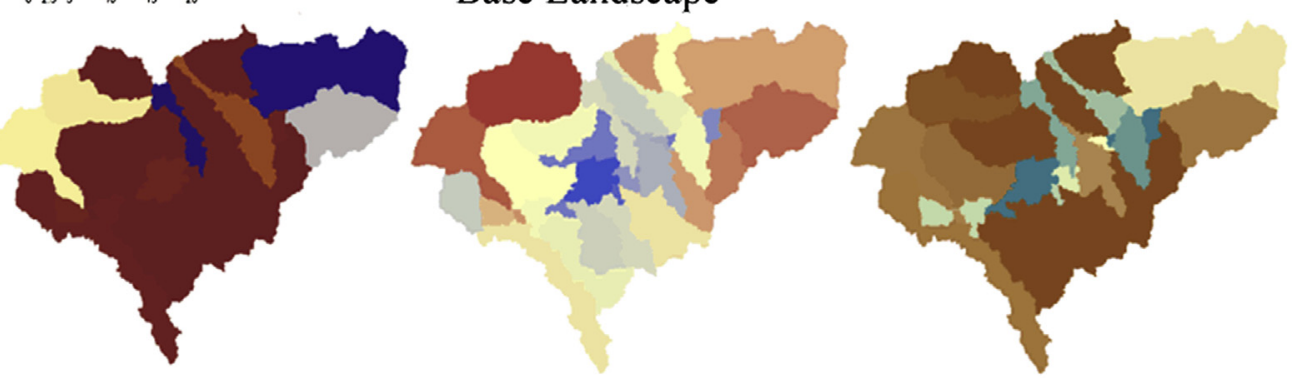

Water conservation
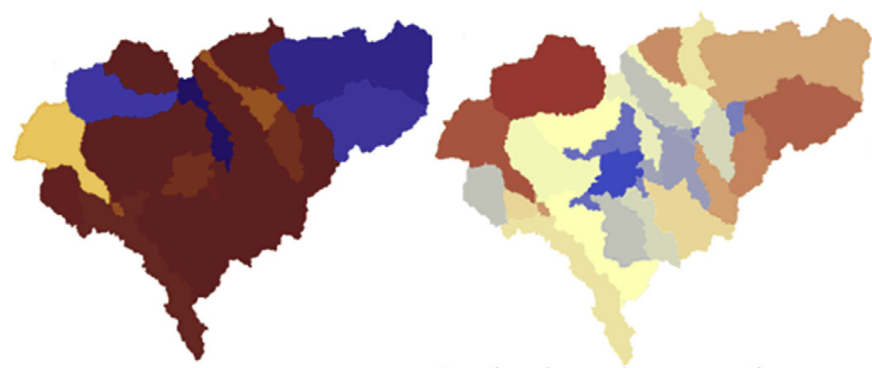

Agricultural expansion


Combined scenario
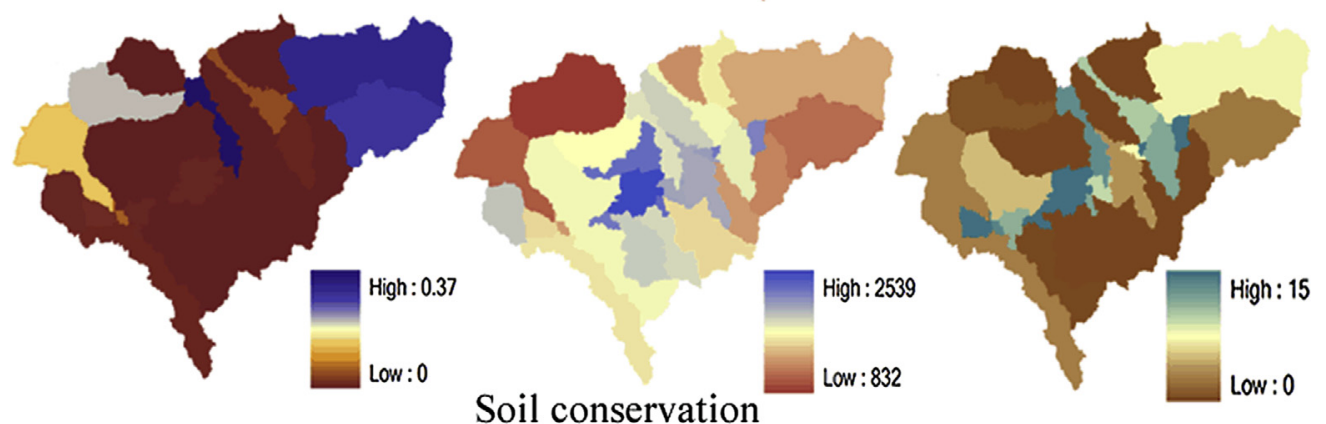

Fig. 3. Maps of ecosystem services under the Base Landscape and four scenarios for (A) soil export (ton/ha), (B) water yield ( $\mathrm{m}^{3} / \mathrm{ha}$ ), and (C)nitrogen export (kg/ha). 


\subsection{Relationships between ecosystem services}

Spatial concordance among ecosystem services on a watershed scale was assessed using quadratic polynomial regression models that were verified to perform best for the study area after fitting other classic regression models. Interactions were visualized by plotting the production correlations of ecosystem services against each other at the sub-basin level. Soil exports and nitrogen exports were found to have significant $(\mathrm{P}<0.01)$ correlations with water yield at different levels. By matching spatially distributed data at the sub-basin level, water yield related best with soil exports $\left(\mathrm{R}^{2}>0.5\right)$ among all pair-wise relationships. The relationships between water yield and soil export were strengthened after adding 100 -m buffer strips (Table 4 ). Water yields showed strong $\left(R^{2}>0.5\right)$ positive correlations with nitrogen exports under the baseline, water conservation, agricultural expansion, and soil conservation scenarios as well as a moderate $\left(0.5>\mathrm{R}^{2}>0.2\right)$ correlation under the combined scenario. Soil exports also showed strong positive correlations with nitrogen exports under the baseline, water conservation, and soil conservation scenarios, as well as moderate $\left(0.5>R^{2}>0.2\right)$ correlations under the combined and agricultural expansion scenarios. The comparison of the land-use scenarios in terms of ecosystem service provision showed a synergy between soil conservation and water purification. The results also indicated the tradeoff between water yield and soil conservation as water yield was found to increase with an increase in soil exports. In addition, a tradeoff between water yield and water purification was present, as water yield was positively correlated with nitrogen export.

\section{Discussion}

Land-use changes in the Guishui River Basin have strongly affected ecosystem services including water yield, nitrogen exports, and soil exports. Various studies have explored the impacts of landuse change on water yield (Egoh et al., 2008; López-Moreno et al., 2011; Wang et al., 2015). Generally, conversion of cropland to woodland results in increased $\mathrm{ET}_{\mathrm{a}}$ and decreased water yield. Consequently, under the conservation scenario, water yield decreased by $3.8 \%$ because of lower $\mathrm{ET}_{\mathrm{a}}$. The water conservation scenario provided a double benefit in terms of a significant decrease in nitrogen exports and soil exports [similar to Goldstein et al. (2012) and Harmáčková and Vačkář (2015)]. The agriculture expansion scenario resulted in a decrease of water yield and an increase of nitrogen and soil exports. The results indicated that agricultural expansion led to water quality degradation and soil loss; however, it also led to increased agricultural production.

Land-use changes such as agricultural expansion and urbanization increase nitrogen exports, which can lead to deterioration in water quality (Borjesson and Tufvesson, 2011). Best management practice has been widely recognized as an effective way to improve downstream water quality in both urban and rural areas (Perales-Momparler et al., 2015; Greenway, 2017). Creating buffer strips to reduce runoff is a well-established agricultural best management practice (Goldstein et al., 2012). In this study, water quality improved dramatically by adding $100-\mathrm{m}$ buffer strips, with decreases in nitrogen and soil exports. This supports the findings of Polasky et al. (2010). Compared with the same scenario without buffers (agricultural expansion scenario), the combined scenario can achieve a $4.9 \%$ and $9.6 \%$ reduction in nitrogen and soil exports, respectively. Therefore, the combined scenario presented a better option in comparison with the baseline and agricultural expansion scenario owing to the reduction of pollutants and increased agricultural production.

This research focused strictly on water yield, water quality, and soil conservation, but the planning scenarios would affect differentially other ecosystem services that we did not quantify. For example, agricultural production services would decrease in the soil conservation scenario, in which the croplands were converted to grasslands. Alternatively, agricultural production services would be enhanced by the agricultural expansion scenario. Using additional models to quantify agricultural production and other ecosystem services (e.g., carbon storage, flood mitigation, raw material supply, and pollination) would further strengthen the planning processes with information supporting (Tao et al., 2015; Sun et al., 2017).

Several factors affected the accuracy of estimating ecosystem services (Wang et al., 2015). Water yield was calculated on an annual basis using annual average precipitation, which ignores the impact of extreme rainfall events. The seasonal and inter-annual variability of precipitation is also a major cause of uncertainty (Jia et al., 2014). Further improvements in modeling and data are needed to increase the reliability of estimates of ecosystem services. We have not used sensitivity analysis in this paper to systematically explore the effect of uncertainty in ecosystem service provision. Such analysis is clearly worth pursuing in the future.

\section{Conclusions}

In this paper, the InVEST model was used to compare the effects of past land-use change and future scenarios on water yield, water purification, and soil conservation in the Guishui River Basin. The results showed the Guishui River Basin experienced a conversion of land use from cropland and grassland to woodland and construction land from 1980 to 2011. These land-use changes altered the provision of ecosystem services. Specifically, water yield and nitrogen exports increased by $8 \%$ and $5.6 \%$, and soil exports decreased by $5.1 \%$. Water yield and soil conservation were enhanced, while water purification was degraded as a result of the combined effects of reforestation and urbanization. Based on analysis of the factors that have driven past land-use changes, four possible futures scenarios of landscape development were created to explore the impacts of future land-use change on ecosystem services. The water conservation scenario performed well in soil conservation and water purification and relatively poorly on water yield. Agricultural expansion may result in deterioration in water quality as a result of increases in nitrogen exports. Adding forest buffer strips could mitigate such pollution. Water yield, soil conservation, and water purification were all greatly enhanced in the soil conservation scenario. Integrating ecosystem services into land-use planning and management is still a challenge and rarely done. This study assessed the impacts of land-use change on water-related

Table 4

Relationships between ecosystem services under different scenarios.

\begin{tabular}{|c|c|c|c|c|c|c|c|c|c|c|}
\hline & \multicolumn{2}{|c|}{ Base landscape } & \multicolumn{2}{|c|}{ Water conservation } & \multicolumn{2}{|c|}{ Agricultural expansion } & \multicolumn{2}{|c|}{ Combined scenario } & \multicolumn{2}{|c|}{ Soil conservation } \\
\hline & Soil export & Nitrogen export & Soil export & Nitrogen export & Soil export & Nitrogen export & Soil export & Nitrogen export & Soil export & Nitrogen export \\
\hline Water yield & 0.789 & 0.589 & 0.838 & 0.558 & 0.73 & 0.548 & 0.829 & 0.415 & 0.745 & 0.65 \\
\hline Soil export & 1 & 0.559 & 1 & 0.55 & 1 & 0.483 & 1 & 0.416 & 1 & 0.596 \\
\hline
\end{tabular}


ecosystem services and the results would be useful for those policymakers and stakeholders that intend to forecast the impacts of alternative land-use policies on water-related ecosystem services. This research provided with three policy implications on land-use planning: (1) Vegetation buffer strip along the river can effectively mitigate negative effects of surrounding agriculture land; (2) In order to reduce soil loss, it is suggested to replace agriculture land with grassland in sloping highland areas; (3) Green spaces and wetlands are the essential ecological infrastructures in improving water quality and should be protected in urban areas.

\section{Acknowledgments}

This research was financially supported by the National Natural Science Foundation of China (No. 71273254, 71533004). We also express our gratitude to the reviewers and editors for their comments on the manuscript.

\section{References}

Bai, Y., Ouyang, Z., Zheng, H., Li, X., Zhuang, C., Jiang, B., 2012. Modeling soil conservation, water conservation and their tradeoffs: a case study in Beijing. J. Environ. Sci. 24, 419-426.

Bennett, E.M., Peterson, G.D., Gordon, L.J., 2009. Understanding relationships among multiple ecosystem services. Ecol. Lett. 12, 1394-1404.

Borjesson, P., Tufvesson, L.M., 2011. Agricultural crop-based biofuels-resource efficiency and environmental performance including direct land use changes. J. Clean. Prod. 19, 108-120.

Cao, V., Margni, M., Favis, B.D., Deschênes, L., 2015. Aggregated indicator to assess land use impacts in life cycle assessment (LCA) based on the economic value of ecosystem services. J. Clean. Prod. 94, 56-66.

Chuai, X., Huang, X., Wang, W., Zhao, R., Zhang, M., Wu, C., 2015. Land use, tota carbon emissions change and low carbon land management in Coastal Jiangsu, China. J. Clean. Prod. 103, 77-86.

de Groot, R.S., Alkemade, R., Braat, L., Hein, L., Willemen, L., 2010. Challenges in integrating the concept of ecosystem services and values in landscape planning management and decision making. Ecol. Complex. 7, 260-272.

Egoh, B., Reyers, B., Rouget, M., Richardson, D.M., Le Maitre, D.C., van Jaarsveld, A.S., 2008. Mapping ecosystem services for planning and management. Agric. Ecosyst. Environ. 127, 135-140.

Estoque, R.C., Murayama, Y., 2012. Examining the potential impact of land use/cover changes on the ecosystem services of Baguio city, the Philippines: a scenariobased analysis. Appl. Geogr. 35, 316-326.

Fisher, B., Turner, R.K., Morling, P., 2009. Defining and classifying ecosystem services for decision making. Ecol. Econ. 68, 643-653.

Geneletti, D., 2013. Assessing the impact of alternative land-use zoning policies on future ecosystem services. Environ. Impact Assess. Rev. 40, 25-35.

Goldstein, J.H., Caldarone, G., Duarte, T.K., Ennaanay, D., Hannahs, N., Mendoza, G. Polasky, S., Wolny, S., Daily, G.C., 2012. Integrating ecosystem-service tradeoffs into land-use decisions. Proc. Natl. Acad. Sci. U. S. A. 109, 7565-7570.

Greenway, M., 2017. Stormwater wetlands for the enhancement of environmental ecosystem services: case studies for two retrofit wetlands in Brisbane, Australia J. Clean. Prod. 163, S91-S100. http://dx.doi.org/10.1016/j.jclepro.2015.12.081.

Hamel, P., Chaplin-Kramer, R., Sim, S., Mueller, C., 2015. A new approach to modeling the sediment retention service (InVEST 3.0): case study of the Cape Fear catchment, North Carolina, USA. Sci. Total Environ. 524-525, 166-177.

Harmáčková, Z.V., Vačkár̆, D., 2015. Modelling regulating ecosystem services tradeoffs across landscape scenarios in Třeboňsko Wetlands Biosphere Reserve, Czech Republic. Ecol. Model. 295, 207-215.
He, G., Fang, H., Bai, S., et al., 2011. Application of a three-dimensional eutrophication model for the Beijing Guanting Reservoir, China. Ecol. Model. 222, 1491-1501.

He, C., Zhang, D., Huang, Q., et al., 2016. Assessing the potential impacts of urban expansion on regional carbon storage by linking the LUSD-urban and InVEST models. Environ. Model. Softw. 75, 44-58.

Jia, X., Fu, B., Feng, X., Hou, G., Liu, Y., Wang, X., 2014. The tradeoff and synergy between ecosystem services in the grain-for-green areas in Northern Shaanxi, China. Ecol. Indic. 43, 103-113.

López-Moreno, J.I., Vicente-Serrano, S.M., Moran-Tejeda, E., Zabalza, J., LorenzoLacruz, J., García-Ruiz, J.M., 2011. Impact of climate evolution and land use changes on water yield in the ebro basin. Hydrol. Earth Syst. Sci. 15, 311-322.

Logsdon, R.A., Chaubey, I., 2013. A quantitative approach to evaluating ecosystem services. Ecol. Model. 257, 57-65.

Millennium Ecosystem Assessment (MA), 2005. Millennium Ecosystem Assessment Synthesis Report. Island Press, Washington, D.C.

Nelson, E., Sander, H., Hawthorne, P., Conte, M., Ennaanay, D., Wolny, S., Manson, S. Polasky, S., 2010. Projecting global land-use change and its effect on ecosystem service provision and biodiversity with simple models. PLoS One 5, e14327.

Perales-Momparler, S., Andrés-Doménech, I., Andreu, J., Escuder-Bueno, I., 2015 A regenerative urban stormwater management methodology: the journey of a Mediterranean city. J. Clean. Prod. 109, 174-189.

Polasky, S., Nelson, E., Pennington, D., Johnson, K.A., 2010. The impact of land-use change on ecosystem services, biodiversity and returns to landowners: a case study in the state of Minnesota. Environ. Resour. Econ. 48, 219-242.

Priess, J., Mimler, M., Klein, A., Schwarze, S., Tscharntke, T., 2007. Linking deforestation scenarios to pollination services and economic returns in coffee agroforestry systems. Ecol. Appl. 17, 407-417.

Ricketts, T.H., Regetz, J., Steffan-Dewenter, I., Cunningham, S.A., Kremen, C., Bogdanski, A., Gemmill-Herren, B., Greenleaf, S.S., Klein, A.M., Mayfield, M.M. Morandin, L.A., Ochieng, A., Potts, S.G., Viana, B.F., 2008. Landscape effects on crop pollination services: are there general patterns? Ecol. Lett. 11, 499-515.

Seppelt, R., Dormann, C.F., Eppink, F.V., Lautenbach, S., Schmidt, S., 2011. A quantitative review of ecosystem service studies: approaches, shortcomings and the road ahead. J. Appl. Ecol. 48, 630-636.

Shoyama, K., Yamagata, Y., 2014. Predicting land-use change for biodiversity conservation and climate-change mitigation and its effect on ecosystem services in a watershed in Japan. Ecosyst. Serv. 8, 25-34.

Sun, X., Li, Y., Zhu, X., Cao, K., Feng, L., 2017. Integrative assessment and management implications on ecosystem services loss of coastal wetlands due to reclamation. J. Clean. Prod. 163, S101-S112. http://dx.doi.org/10.1016/j.jclepro.2015.10.048.

Tallis, H., Polasky, S., 2009. Mapping and valuing ecosystem services as an approach for conservation and natural-resource management. Ann. N. Y. Acad. Sci. 1162, $265-283$.

Tallis, H., Ricketts, T., Guerry, A., Wood, S., Sharp, R., 2013. InVEST 2.5.6 User's Guide. The Natural Capital Project, Stanford.

Tao, Y., Li, F., Wang, R., Zhao, D., 2015. Effects of land use and cover change on terrestrial carbon stocks in urbanized areas: a study from Changzhou, China. J. Clean. Prod. 103, 651-657.

Vigerstol, K.L., Aukema, J.E., 2011. A comparison of tools for modeling freshwater ecosystem services. J. Environ. Manag. 92, 2403-2409.

Villa, F., Bagstad, K.J., Voigt, B., Johnson, G.W., Portela, R., Honzak, M., Batker, D. 2014. A methodology for adaptable and robust ecosystem services assessment. PLoS One 9, e91001.

Wang, Z., Mao, D., Li, L., Jia, M., Dong, Z., Miao, Z., Ren, C., Song, C., 2015. Quantifying changes in multiple ecosystem services during 1992-2012 in the Sanjiang Plain of China. Sci. Total Environ. 514, 119-130.

Xu, Y., Huang, K., Yu, Y., Wang, X., 2015. Changes in water footprint of crop production in Beijing from 1978 to 2012: a logarithmic mean Divisia index decomposition analysis. J. Clean. Prod. 87, 180-187.

Zheng, H., Robinson, B.E., Liang, Y.C., Polasky, S., Ma, D.C., Wang, F.C., Ruckelshaus, M., Ouyang, Z.Y., Daily, G.C., 2013. Benefits, costs, and livelihood implications of a regional payment for ecosystem service program. Proc. Natl. Acad. Sci. U. S. A. 110, 16681-16686.

Zhuang, C., Ouyang, Z., Xu, W., Bai, Y., Zhou, W., Zheng, H., Wang, X., 2010. Impacts of human activities on the hydrology of Baiyangdian Lake, China. Environ. Earth Sci. 62, 1343-1350. 